\title{
Using Newly Available Homicide Data to Debunk Two Myths About Violence in an International Context
}

\author{
A Research Note
}

WILLIAM ALEX PRIDEMORE

University of Oklahoma

\begin{abstract}
This article employs newly available crime and vital statistics data from Russia to debunk two myths about violence in an international context. The first myth is that the United States is the most violent industrialized nation in the world. The second myth is that in spite of other problems associated with Soviet society, at least the totalitarian regime was able to maintain low rates of crime and violence. The newly available data reveal the inaccuracies in each of these statements. Not only is the current Russian homicide victimization rate more than 3 times higher than in the United States, but it has been comparable to or higher than the U.S. rate for at least the past 35 years. Furthermore, preliminary analyses of these data also question the generalizability of other commonly held notions about the production of high rates of violence in the United States.
\end{abstract}

Recent years have witnessed an increase in comparative criminological research (for reviews of this work, see Howard, Newman, \& Pridemore, 2000; LaFree, 1999) and calls for country-specific research outside the United States and other Western nations (see Arthur \& Marenin, 1995; Lynch, 1995; Neapolitan, 1997). Accordingly, I report here some preliminary analyses from a crossnational research project that examines the relationship between social structure and rates of lethal violence in Russia, the results of

AUTHOR'S NOTE: This research was supported in part by Grant 1999-IJ-CX-0009 awarded by the National Institute of Justice (NIJ), Office of Justice Programs, U.S. Department of Justice. A draft of this research note was written while serving for a brief time as a guest scholar at the Max Planck Institute for Demographic Research (MPIDR) in Rostock, Germany. Points of view in this document are those of the author and do not necessarily represent the official position or policies of NIJ or MPIDR. I thank Rosemary Gartner, who provided helpful comments and suggestions, and Vladimir Shkolnikov, for his aid in securing the homicide victimization data employed here and for the invitation to MPIDR.

HOMICIDE STUDIES, Vol. 5 No. 3, August 2001 267-275

(C) 2001 Sage Publications 
which challenge some widely held beliefs. The purpose of this research note, therefore, is to employ new data in debunking two popular myths about violence in the United States and in Soviet Russia.

\section{TWO MYTHS}

Even with the decline of the homicide rate in the United States during the 1990s, the 1999 rate of 5.7 per 100,000 population (Federal Bureau of Investigation [FBI], 2000) was still much higher than in most other Western nations. It is usually suggested that only a few countries in Latin America and sub-Saharan Africa have higher levels of interpersonal violence than in the United States. This has led to the first-long standing myth, one often supported by social scientists, policy analysts, and journalists, that the United States is the most violent industrialized nation in the world.

Myth number two is a claim offered both by former Soviet officials and many Western observers of the former Soviet Union, which was usually based on vague and often falsified official crime data reported by government officials. The essence of this claim is that despite the diverse problems associated with Soviet totalitarianism, at least the Soviet Union maintained low rates of crime and violence.

\section{RECENT CRIME DATA FROM RUSSIA}

The long-term benefits of a shift away from totalitarianism and toward rule of law in Russia will likely be many, but short-term benefits have been few. One tangible boon among these few is the slowly expanding transparency of the Russian government. This relative openness has led to an increase in the validity and availability of data related to crime and to Russian society, as well as improvement in the quality of their presentation (Heleniak, 1996; World Bank, 1996). The Russian Ministry of the Interior, for example, now annually publishes several data books with summary statistics on crime and juvenile delinquency, such as Prestupnost' $i$ Pravonarushenia (Russian Ministry of the Interior, 2000a) and 
Prestupnost' Nesovershennoletnikh $v$ Rossii (Russian Ministry of the Interior, 2000b). Furthermore, the Russian State Committee for Statistics (Goskomstat) produces a wide range of publications with social and economic indicators, such as Demograficheskii Ezhegodnik (Goskomstat, 1997) and Rossiiskii Statisticheskii Ezhegodnik (Goskomstat, 2000).

At one glance, data on homicide from the Ministry of the Interior quickly reveal the error in the first myth. Figure 1 compares homicide rates from official crime data for Russia and the United States during the 1990s. Aside from the dramatic increase in homicide rates in Russia during the early years of the decade (and a concomitant decline in the United States), these data make it clear that the United States is not the most violent industrialized nation in the world, at least in terms of homicide rates. The Russian homicide rate was comparable to that in the United States at the beginning of the 1990s, and the 1999 rate of a little more than 21 per 100,000 population (Russian Ministry of the Interior, 2000c) was nearly 4 times greater than the rate of 5.7 per 100,000 in the United States (FBI, 2000). ${ }^{1}$

These crime data, however, only reveal rates for the 1990s and say nothing about the second myth. It might reasonably be argued, given the repeated crises faced by Russia during the past 10 to 15 years, that these extremely high annual homicide rates reflect a period effect, especially because the rate in 1990 (a few years after the initial social, political, and economic difficulties had begun) was still similar to that in the United States. In other words, a Russian homicide rate comparable with that in America may only be an artifact of the transition, leaving us comfortable in the commonly accepted belief that the level of lethal violence in Russia during the Soviet era was still much lower than in the United States.

\section{VITAL STATISTICS DATA}

As in the United States, information on homicide in Russia is available from both crime data and a national vital statistics registration system. Mortality data are commonly considered to provide a better representation of the total number of homicides than are crime data (Fox \& Zawitz, 2000; Rokaw, Mercy, \& Smith, 1990), 


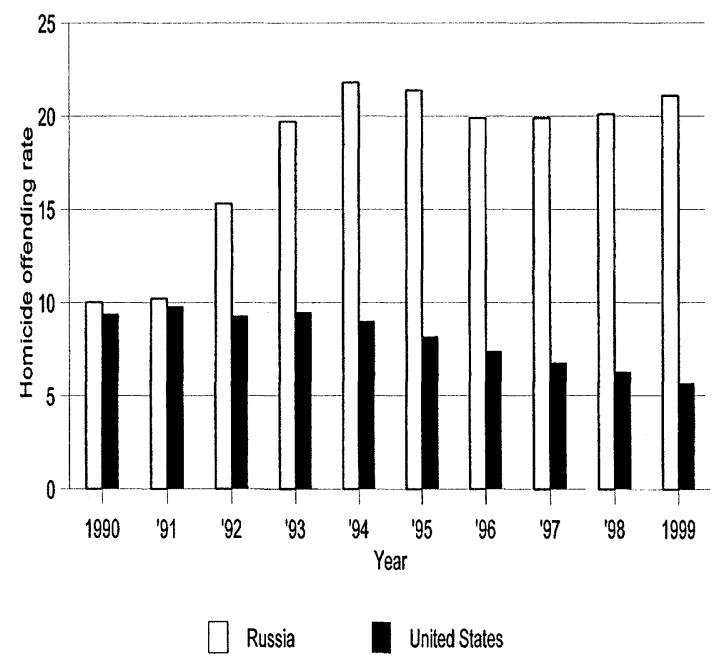

Figure 1: Annual Homicide Rates per 100,000 Persons According to Official Crime Data From Russia and the United States, 1990-1999

SOURCE: Adapted from Russian Ministry of the Interior $(1996,2000 a)$ and Federal Bureau of Investigation (1966-1999).

and this is especially true when undertaking international research (LaFree, 1999). For several reasons that are beyond the scope of this work, the same is true for Russia as well. (For a complete discussion of the measurement of homicide in Russia, see Pridemore, 2000.) One obvious example is that crime data from the Russian Ministry of the Interior annually reported less than $75 \%$ of the total number of homicides reported by the Ministry of Health's mortality data during the 1990s, and this despite the fact that the homicide category in the crime data includes attempts.

Access to vital statistics data was restricted during the Soviet era, and these data were completely unavailable to the public from 1974 to 1986 (Shkolnikov \& Meslé, 1996). Furthermore, from 1965 to 1987, deaths due to homicide, suicide, several types of infectious diseases, and occupational injuries were removed from the original tables and recorded on a special form, 5B. The number of homicide deaths were counted, but this number remained classified, and in public documents, they were reported in the "other and unknown causes" category (Andreev, Scherbov, \& Willekens, 1995). This practice was halted in 1988 , and mortality data are now publicly available from both the Ministry of Health (see Russian 
Ministry of Health, 1999) and Goskomstat (see Note 1). A small group of researchers has employed these newly available data to reconstruct the actual number of deaths due to specific causes back to 1965 thereby removing homicides from the "other" classification and placing them into the appropriate category (see Meslé, Shkolnikov, Hertrich, \& Vallin, 1996). ${ }^{2}$

Figure 2 employs mortality data from the United States and Russia to compare the age-standardized homicide victimization rates of the two nations from 1965 to 1998. Using these newly reconstructed mortality data to reveal homicide victimization rates back to 1965 makes it evident that crime in Soviet Russia, or at least the homicide rate, was not as low as previously advertised.

Figure 2 reveals that the annual homicide victimization rate in Russia has been comparable with or greater than the rate in the United States for at least the past three and a half decades. The U.S. rate was slightly higher from 1965 to 1975, and the Russian rate was then higher until 1985. However, with the exception of a slight dip in U.S. rates in the mid-1970s, the homicide victimization rates in both countries followed remarkably similar patterns from the mid-1960s until the dramatic changes in Russia in the mid- to late-1980s. ${ }^{3}$ Thus, the vital statistics data strengthen our support for the dismantling of myth number two.

Finally, I briefly note here that further preliminary analyses of these data also appear to question some of our notions about why a country might have such high rates of violence. For example, legal restrictions on firearms in Russia mean that there is a relatively low gun homicide rate in the country. Furthermore, the Russian data suggest that homicide rates in small towns and rural areas are not significantly lower than found in large cities; in contrast, researchers, such as Parker (1989) and Kovandzic, Vieraitis, and Yeisley (1998), have referred to homicide in the United States as a center-city phenomenon. Finally, the age pattern of both homicide victims and offenders in Russia raises questions about the invariance of the age-crime curve, at least as it relates to lethal violence.

These preliminary findings from Russia obviously do not mean that ready access to firearms and the structural conditions characteristic of large American cities do not matter in the United States. They do mean, however, that our obsession with our own high rates might have (a) led us to ignore other structural and cultural 


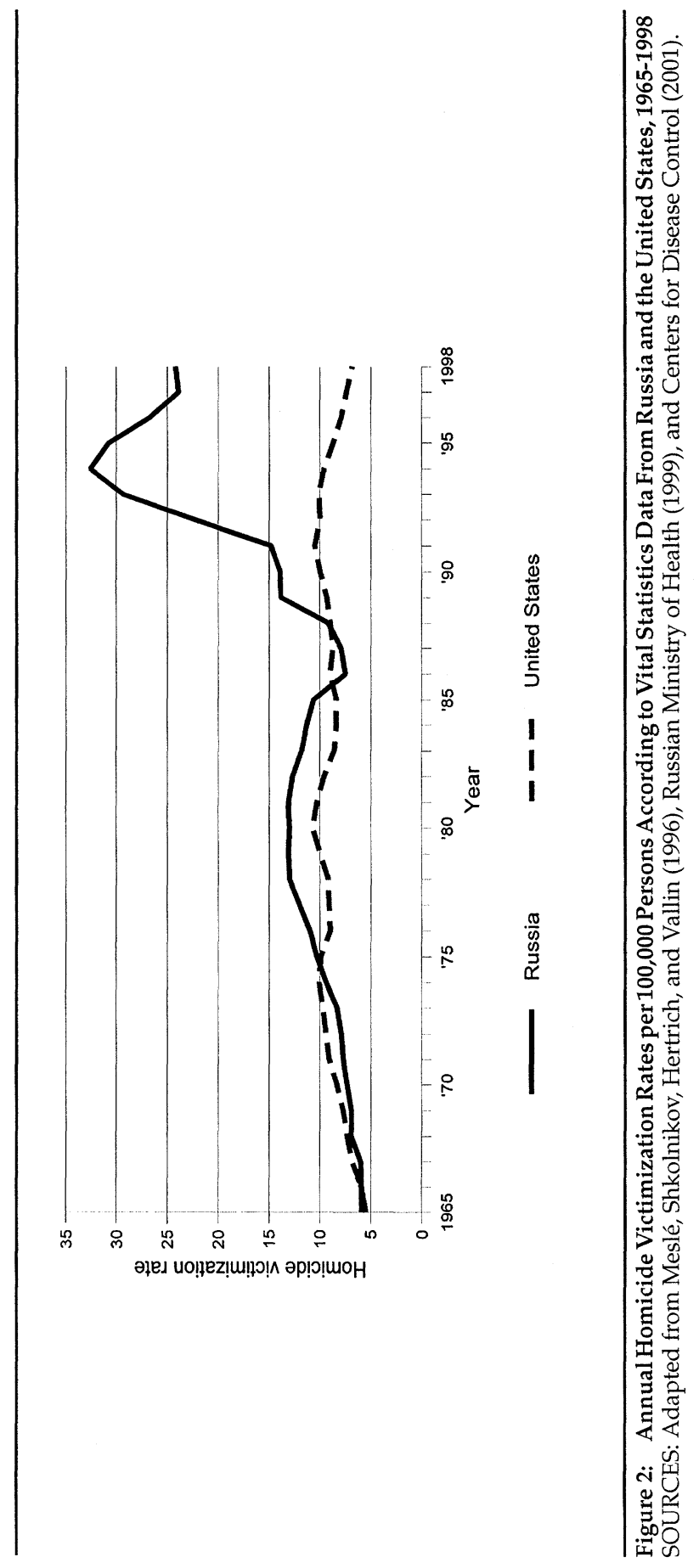


features that might be important in the production of high rates of violence (i.e., we may have discovered some causes of high rates of violence, but not the causes) or (b) kept us from recognizing that some of the causes of our high rates may be country specific.

\section{SUMMARY AND CONCLUSION}

The benefits of comparative criminological research are both local and universal. Criminological research in different nations can reveal situations specific to the nation that might influence rates of crime. At the same time, by comparing these results to other nations we are able to test the reliability of our theories and to test our widely held assumptions about crime.

The descriptive results reported here say little about theory, but they do convince us of errors in two commonly accepted beliefs about violence in an international context - that the United States has long been the most violent industrialized nation in the world and that levels of lethal violence were low in Soviet Russia. These results suggest, then, that it is necessary to undertake further and more methodologically sound international and comparative research to discover whether the factors commonly associated with high rates of violence in the United States are generalizable to other nations or whether they may be culture specific.

\section{NOTES}

1. The validity of Soviet and Russian mortality data, including that related to violent death, has been the subject of continued scrutiny. For a detailed discussion of their validity, of different methodologies employed to evaluate their validity, and of the positive results, see Anderson, Katus, and Silver (1994); Anderson and Silver (1997); Shkolnikov and Meslé (1996); and Wasserman and Varnik (1998).

2. Until 1999, Russia used the Soviet coding scheme for causes of death. The code numbers were different from the International Classification of Diseases (ICD) codes, but for homicide (and most other causes) the definition was the same. Thus, the Russian code of 174 was the same as ICD items E960-E978, with both containing deaths due to homicide and injury purposely inflicted by other persons, including legal interventions and executions.

3. Raw data from the Russian Ministry of Health also show a rise in the number of "unspecified violent deaths" throughout the 1990s (number 175 in the Russian coding scheme), hinting that large numbers of homicides are possibly being misclassified thereby underestimating the homicide victimization rate. 


\section{REFERENCES}

Anderson, B. A., Katus, K., \& Silver, B. D. (1994). Developments and prospects for population statistics in countries of the former Soviet Union. Population Index, 60, 4-20.

Anderson, B. A., \& Silver, B. D. (1997). Issues of data quality in assessing mortality trends and levels in the New Independent States. In J. L. Bobadilla, C. A. Costello, \& F. Mitchell (Eds.), Premature death in the New Independent States (pp. 120-155). Washington, DC: National Academy Press.

Andreev, E., Scherbov, S., \& Willekens, F. (1995). Sources of information on the population of Russia. Groningen, The Netherlands: University of Groningen Press.

Arthur, J., \& Marenin, O. (1995). Explaining crime in developing countries: The need for a case study approach. Crime, Law, and Social Change, 23, 191-214.

Centers for Disease Control. (2001). CDC Wonder: Compressed mortality/population data request screen. Retrieved April 1, 2000, from the World Wide Web: http://wonder.cdc.gov/mortsql.html

Federal Bureau of Investigation. (1966-1998). Crime in the United States: Uniform crime reports. Washington, DC: Government Printing Office.

Federal Bureau of Investigation. (2000). Crime in the United States, 1999. Retrieved December 2, 2000, from the World Wide Web: http://www.fbi.gov/ucr/Cius_99/99crime/ 99c2_03.pdf

Fox, J. A., \& Zawitz, M. W. (2000). Homicide trends in the United States. Retrieved January 3, 2000, from the World Wide Web: http://www.ojp.usdoj.gov/bjs/homicide/ homtrnd.htm

Goskomstat Rossii. (1997). Demograficheskii ezhegodnik [Demographic yearbook of Russia]. Moscow: Author.

Goskomstat Rossii. (2000). Rossiiskii statisticheskii ezhegodnik [Russian statistical yearbook]. Moscow: Author.

Heleniak, T. (1996). Russia's age structure in 1996: A research report. Post-Soviet Geography and Economics, 37, 386-395.

Howard, G. J., Newman, G., \& Pridemore, W. A. (2000). Theory, method, and data in comparative criminology. In D. Duffee (Ed.), Criminal justice 2000: Measurement and analysis of crime and justice (Vol. 4, pp. 139-211). Washington, DC: National Institute of Justice.

Kovandzic, T. V., Vieraitis, L. M., \& Yeisley, M. R. (1998). The structural covariates of urban homicide: Reassessing the impact of income inequality and poverty in the post-Reagan era. Criminology, 36, 569-599.

LaFree, G. (1999). A summary and review of cross-national comparative studies of homicide. In M. D. Smith \& M. A. Zahn (Eds.), Homicide: A sourcebook of social research (pp. 125-145). Thousand Oaks, CA: Sage.

Lynch, J. P. (1995). Building data systems for cross-national comparisons of crime and criminal justice policy: A retrospective. ICPSR Bulletin, 15(3), 1-6.

Meslé, F., Shkolnikov, V. M., Hertrich, V., \& Vallin, J. (1996). Tendances récentes de la mortalité par cause en Russie, 1965-1994 [Recent patterns of mortality by cause in Russia]. Paris: Institut National D'études Démographiques.

Neapolitan, J. L. (1997). Cross-national crime: A research review and sourcebook. Westport, CT: Greenwood.

Parker, R. N. (1989). Poverty, subculture of violence, and type of homicide. Social Forces, 67, 983-1007.

Pridemore, W. A. (2000). Social structure and homicide in post-Soviet Russia. Unpublished doctoral dissertation, University at Albany, State University of New York.

Rokaw, W. M, Mercy, J. A., \& Smith, J. C. (1990). Comparing death certificate data with FBI crime reporting statistics on U. S. homicides. Public Health Reports, 105, 447-455. 
Russian Ministry of Health. (1999). Smertnost' naseleniia Rossiiskoi Federatsii, 1998 god [Population mortality of the Russian Federation, 1998]. Moscow: Author.

Russian Ministry of the Interior. (1996). Prestupnost' i pravonarusheniya, 1991-1995. Statisticheskii sbornik [Crime and offenses, 1991-1995. Statistical collection]. Moscow: Author.

Russian Ministry of the Interior. (2000a). Prestupnost' i pravonarusheniya, 1999. Statisticheskii sbornik [Crime and offenses, 1999. Statistical collection]. Moscow: Author.

Russian Ministry of the Interior. (2000b). Prestupnost' nesovershennoletnikh $v$ Rossii, 1995$1999 \mathrm{gg}$. [Juvenile delinquency in Russia, 1995-1999]. Moscow: Author.

Russian Ministry of the Interior. (2000c). Sostayanie prestupnosti v Rossii za 1999 god [The conditions of crime in Russia in 1999]. Moscow: Author.

Shkolnikov, V., \& Meslé, F. (1996). The Russian epidemiological crisis as mirrored by mortality trends. In J. DaVanzo (Ed.), Russia's demographic "crisis" (pp. 113-162). Santa Monica, CA: RAND.

Wasserman, D., \& Varnik, A. (1998). Reliability of statistics on violent death and suicide in the former USSR, 1970-1990. Acta Psychiatrica Scandinavica (Suppl.), 394, 34-41.

World Bank. (1996). Statistical handbook 1996: States of the former USSR. Washington, DC: Author.

William Alex Pridemore is an assistant professor of sociology at the University of Oklahoma, where he is also an affiliate faculty member of the International and Area Studies Program. His current research examines the effects of social structure, economic transition, and alcohol consumption on lethal violence (including homicide and suicide) in Russia. 